\title{
ERRATUM
}

\section{ANCESTRAL O'ODHAM: AKIMEL O'ODHAM CULTURAL TRADITIONS AND THE ARCHAEOLOGICAL RECORD-ERRATUM}

Chris Loendorf and Barnaby V. Lewis

DOI: https://doi.org/10.1017/aaq.2016.17, Published by Cambridge University Press, 2 February 2017.

References to the O'Odham tribe were written as O'Odhams. The correct form is O'Odham. The error was introduced after the final proof had been approved by the author.

\section{Reference}

